\title{
The Impact of Working Capital, Return on Assets and Return on Equity on Corporate Income Tax
}

\author{
Nikke Yusnita Mahardini \\ Faculty of Economic and Business \\ Universitas Serang Raya
}

\begin{abstract}
This study aims to examine the effect of working capital, Return on Assets (ROA), and Return on Equity (ROE) on corporate income tax. The population of this study is mining companies, and the total sample was involved is thirty-six companies. The data used in the study is in the form of financial statements obtained from the Indonesia Stock Exchange (IDX). The data analysis method used in this study is the multiple regression analysis. Results of the study indicate that working capital significantly influences corporate income tax. Meanwhile, Return on Assets (ROA) and Return on Equity (ROE) are not significant to explain the variance of corporate income tax. Simultaneously, working capital, Return on Assets (ROA) and Return on Equity (ROE) as a function of corporate income tax were found significant
\end{abstract}

Keywords: Working Capital; Return on Asset; Return on Equity; Corporate income tax

\section{Introduction}

Today the business environment is very competitive. Therefore, the company certainly needs to run management functions, namely planning, organizing, and controlling correctly so that the company can achieve the organization goals. Furthermore, the company also needs to carry out capital management properly so that sufficient capital is available in carrying out the increase in operational activities. Every company needs working capital to finance its daily operations. Working capital is a company investment in the form of cash, securities, accounts receivable, and inventory.

Proper management of working capital is essential so that the continuity of business can be maintained and to avoid bankruptcy. If the working capital is too large or exceeds the need, it indicates that the working capital is not used optimally. Idle working capital can encourage manipulation and pass the opportunity to achieve the company target profits.
On the other hand, if the working capital is too small, it will disrupt the operations of the company. Low of working capital is a threat for the company in terms of capability in financing operational process so that it ultimately lowers the potential profit. Therefore, it is necessary to conduct right management policies to determine the amount and composition of working capital used in carrying out company activities. Working capital needs to be used efficiently so that the acquisition of resources and the use of working capital can increase the company's profitability.

Information on company financial performance, especially profitability, is needed to assess potential changes in economic resources in the future. Financial performance information is useful for predicting a company's capacity to generate cash flows from existing resources. As additional, financial information is also a valuable consideration to measure the effectiveness of the company in utilizing additional resources. Taxes for companies are costs and also expenditures whose 
benefits are not received directly, either in the form of goods, services, or funds. Therefore, tax expenditures must be taken into account in every decision that involves them. The tax calculation is based on the financial statements or bookkeeping made by the issuer. Accounting reporting and tax reporting serve different stakeholders with different objectives. Therefore, managers have different policies in calculating both accounting income and taxable income. Based on the explanation mentioned above, the research problems are formulated as follows: 1) does the use of working capital affect the corporate income tax?;2) does the return on assets affect the corporate income tax?; 3) does the return on equity affect the corporate income tax?; 4) does the use of working capital return on assets and return on equity have a simultaneous effect on corporate income tax?

Firstly, the purpose of this study is to examine individual the impact of using working, return on asset, return on equity capital on corporate income tax. Secondly, the study tested the model that working capital, return on asset, return on equity capital are a function of corporate income $\operatorname{tax}$

\section{Literature Review and Hypothesis Development}

\section{Working Capital}

Every company needs working capital to finance its daily operations such as a purchase of raw materials, pay labor wages, and employee salaries. The financial resources that have been spent are expected to be able to return to the company within a period. The revenues from the sale of the product will soon be allocated again to finance the next operation. Thus, the fund will continue to rotate every period during the operation of the company.

According to Harahap (2013: 2008): "Working capital is current assets minus current debt. Working capital is a measure of the interests of short-term creditors.
Working capital is also considered as available funds to be invested in noncurrent assets or to pay a non-current debt". Adequate working capital will allow a company to operate as economically as possible, but excessive working capital indicates the existence of unproductive funds, and this will cause losses to the company. Conversely, the inadequacy of working capital is the primary indicator of a company's failure. The use of working capital will cause a decrease in the number of current assets owned by the company. However, the change or decrease do not always follow the use of current assets in the amount of working capital owned by the company.

According to S. Munawir (2010: 14), there are three concepts or definitions of working capital that are commonly used, namely, quantitative concepts, qualitative concepts, and functional Concepts. The quantitative concept focuses on the quantum needed to meet the company's needs to finance its routine operations or show the number of funds available for short-term operations. In this concept, It is assumed that working capital is the number of current assets (gross working capital). Qualitative concept focus on the quality of working capital, in this concept working capital, is the excess of current assets against short-term debt (net working capital), namely the number of current assets derived from long-term loans as well as from the owners of the company. The functional concept focuses on the function of the funds held in order to generate income (profits) from the company's main business. The funds owned by the company will be used to generate profits under the main business of the company. However, not all funds are used to generate profits. There are some funds used to obtain or generate profits in the future, such as buildings, factory machinery, office equipment, and other fixed assets.

Working capital has several functions. First, working capital accommodates the possibility of adverse 
consequences caused by a decrease in the value of current assets such as a decrease in the value of doubtful and uncollectible receivables or a decrease in the value of inventories. Second, adequate working capital allows the company to pay all its current debt on time. Third, adequate working capital allows the company to maintain the credit rating of the company. Fourth, working capital enables companies to provide credit to buyers. Fifth, working capital enables the company to provide inventory at a sufficient amount. Sixth, working capital enables company leaders to organize companies more efficiently by avoiding delays in obtaining materials, services, and tools caused by credit difficulties. Seventh, adequate working capital, allows the company to face a period of recession and depression well.

The use of working capital will cause a decrease in the number of current assets owned by the company. However, the decrease in current assets is not always followed by the increasing amount of working capital owned by the company. The use of working capital according to Kasmir (2012: 258) is; 1) expenditures for salaries, wages, and other operating expenses, 2) expenditures to buy raw materials or merchandise, 3) cover losses due to the sale of securities, 3) establishment of funds, 4) Purchase of fixed assets. The need for working capital is influenced by several factors such as 1) nature or type of company; 2) the time needed to produce or obtain goods to be sold as well as the unity price of the goods; 3 ) terms of purchase of goods or merchandise; 4) terms of sale; 5) inventory turnover rate; 6) seasonal; 7) sales volume;8) accounts turnover rate and 9) the average amount of money spent every day.

\section{Return on Asset (ROA)}

Return on Assets (ROA) is a ratio that shows the return of assets used in the company. ROA is a measure of management effectiveness in terms of the asset used. Also, ROA shows the productivity of all company funds, both loan capital, and own capital. Low ROA ratio indicates poor performance of asset use. According to Harahap (2010: 305), ROA describes asset turnover measured from sales. ROA is a ratio that shows the return of the number of assets used in the company (Kasmir, 2008: 201). The higher ROA ratio indicates the better performance of asset employed. ROA is a ratio that shows how much net income can be obtained from all the assets owned by the company. Therefore, the higher the ratio, the higher the company's ability to generate profits. Return on Assets (ROA) has benefits not only for the business owner or management but also for parties outside the company such as potential investors

Return on Assets (ROA) can measure the efficiency of the use of working capital, production efficiency, and efficiency of the sales department. The efficiency of capital use can be compared with other similar companies so that the position of the company in terms of asset uses performance can be identified. ROA can also be used to measure the efficiency of actions carried out by divisions/sections, namely by allocating all costs and capital into the relevant part. The significance of measuring the rate of return at the section level is to be able to compare the efficiency of a part with another part of the company concerned.

Furthermore, ROA can also be used as indicators to measure the profitability of each product. Thus management will be able to find out which products have the potential profit in the long run. ROA besides useful for planning and control purposes. For company expansion, ROA is fundamental indicators for helping managers make a strategic decision. ROA will change if there is a change in the profit margin or asset turn over. Thus the company leader can use one or both of them to enlarge ROA. According to Munawir (2007: 89), the amount of ROA is influenced by two factors, namely, turn over from operating assets and Profit 
margins. This profit margin measures the level of profit that can be achieved associated with its sales.

\section{Return on Equity (ROE)}

Return on Equity (ROE) is a ratio of net income after tax of the company with its capital. This ratio focuses on how the company's operating efficiency is translated into profits. According to Kasmir (2008: 204), ROE is the ratio of net income after tax with equity. Whereas, Lukman Syamsuddin (2009: 64) stated that ROE is a measurement of income available for owners (both ordinary shareholders and preferred shareholders) for the capital they invest in the company. Therefore, it can be concluded that ROE is a comparison between net income after tax and equity. The higher the return or income earned, the better the position of the company. ROE shows the extent to which the company manages its capital effectively, measures the level of profits from investments that have been made

$\mathrm{ROE}$ is an indicator to measure the success of management in maximizing returns to shareholders. The higher the ROE ratio, the better, because it provides a higher return to shareholders. According to Keown et al. (2001: 105), to increase the rate of return on equity obtained by the following methods: 1) increase sales without increasing proportional expenses and costs, 2) reducing the cost of goods sold or the company's operating expenses, 3) increasing sales or reducing the amount of investment in company assets and 4) Increase the use of debt relative to equity, to a point that does not endanger the financial well-being of the company.

\section{Corporate Income Tax}

Tax in terms of economic perspective is the transfer of resources from the private sector to the public sector. It means that the existence of taxes causes two implication. First, reducing the financial resources of individuals as compensation of public goods and services provided by the government. Second, corporate income is a tax imposed on income received or obtained by the Agency as referred to in the law. In Indonesia context, the subject of corporate income tax are; first, entities established or domiciled in Indonesia. Secondly, entities that are not established or domiciled in Indonesia that conduct business or conduct activities through a business unit in Indonesia. Third, entities that are not established and do not domiciled in Indonesia that receive income from Indonesia.

The object of corporate income tax is income, which is an additional economic capability received or obtained by corporate taxpayers both from Indonesia and from outside Indonesia, which can be used for consumption or to increase the wealth of the entity's taxpayer.

The legal basis for income tax is Law Number 7 of 1983 which then undergoes successive changes from Law Number 7 of 1991, Law Number 10 of 1994, Law Number 17 of 2000, and Law Number 36 of 2008. Based on article 31E paragraph (1) of the Income Tax Law, domestic corporate taxpayers with gross circulation up to $\mathrm{Rp}$ $50,000,000,000$ (fifty billion rupiah) receive facilities in the form of a tariff reduction of $50 \%$ (five-fifty percent of the tariff as referred to in Article 17 paragraph (1) letter b and paragraph (2a) which is imposed on taxable income from the gross circulation to Rp.4,800,000,000.00 (four billion eight hundred million rupiahs).

The tariff reduction facility is under article 31E paragraph (1) of the income tax act carried out through self-assessment when submitting the corporate taxpayer income tax annual notice. Thus, taxpayers do not need to submit a request to obtain the facility. The limit of gross circulation up to Rp 50,000,000,000 (fifty billion rupiahs) is the maximum limit of gross circulation received or obtained by a domestic corporate taxpayer to obtain a tariff 
reduction facility under Article 31E paragraph (1) of the Tax Law Income.

Gross circulation as referred to in Article 31E paragraph (1) of the income tax act is income received or obtained from business activities before deducting costs for obtaining, collecting and maintaining income both from Indonesia and outside Indonesia, including; 1) Income that is subject to Income Tax is final; 2) Income that is subject to income tax is not final; and 3 ) Income excluded from the tax object. The facilities of article 31E paragraph (1) are not an option. As long as the gross circulation accumulation as referred to in letter $\mathrm{c}$ above does not exceed Rp 50,000,000,000 (fifty billion rupiahs), the income tax rate applied to the taxable income of the domestic corporate taxpayer must follow the provisions of the tariff reduction facility in accordance with article 31E paragraph (1) income tax law.

The rights of taxpayers in taxation, namely: the right to receive guidance and direction from the tax authorities, the right to correct, extend the time to submit tax notice, the right to file objections, appeals and claims and a review to the supreme court, the right to obtain excess tax payments, rights in terms of taxpayers are examined, right to get tax facilities, right to apply for installments to pay taxes, delay tax collection, and get compensation from the delay in overpayment of taxes by the directorate general taxation, right to credit input tax on output tax, the right to reduce taxable income with costs incurred according to fiscal costs.

\section{Working Capital and Corporate Income Tax}

Adequate working capital will allow a company to operate as economically as possible, but excessive working capital indicates that there are unproductive funds, and this will cause losses to the company. Conversely, the inadequacy of working capital is the primary indicator of a company's failure. If working capital is managed properly, then the corporate income tax receipt of the deposited corporate will be proper and with good financial reporting. Therefore, the hypothesis is formulated as follows:

Hypothesis 1: Working Capital has a significant impact on corporate income tax.

\section{ROA and Corporate Income Tax}

Return on Assets (ROA) describes asset turnover measured from sales. The higher the ratio, the better, and this means that assets are utilized effectively to gain profits. ROA can measure a company's ability to project profits generated in the future (Harahap, 2010). The overall assets of the company, which are obtained from its capital or from foreign capital that the company has converted into company assets used for the survival of the company. Therefore, if the return on assets in a company is good, it will produce good results of the company's operating profit, which will be reallocated to the corporate income tax payment. Therefore, the hypothesis is formulated as follows:

\section{Hypothesis 2: ROA has a significant impact on corporate income tax.}

\section{ROE and Corporate Income Tax}

ROE is very dependent on the size of the company, for example, for small companies certainly have a relatively small capital, so that the resulting ROE is small, and vice versa for large companies. The higher the ROE ratio, the higher the value of the company, this is an attraction for investors to invest in the company. High ROE will support the profitability of the company and support the deposit of corporate income tax. Therefore, the hypothesis is formulated as follows:

Hypothesis 3: ROE has a significant impact on corporate income tax 
Hypothesis 4: Working Capital, ROA, and ROE have a significant impact on corporate income tax

\section{Methodology}

The types and sources of data used are quantitative data types. The research design was adopted in this study is the causality research. The data sources used are secondary data sources, namely the annual financial statements of mining sub-sector manufacturing companies listed on the Indonesia Stock Exchange for the period 2012-2017. The population in this study is the mining sub-sector manufacturing company listed on the Indonesia Stock Exchange. Purposive sampling technique was employed in this study. The sample of this study were 36 financial report data of mining sub-sector manufacturing companies. There were six companies indicated as an outlier, and it was excluded from the analysis. The data analysis technique was used in this study is multiple regression analysis, with the equation model as follows:

$Y=\alpha+\beta_{1} X_{1}+\beta_{2} X_{2}+\beta_{3} X_{3}+e$

In article 1 of the income tax law, income tax is a tax imposed on the subject of tax on income received or obtained in the tax year. Corporate income tax is the tax imposed on income received or obtained by the agency as referred to the Indonesia tax law. Corporate income tax was measured by a ratio scale that used the following formula:

Corporate Income Tax $=25 \% x$ Taxable income

Adequate working capital will allow a company to operate efficiently, but excessive working capital indicates that there is an unproductive use of assets, and this will cause losses to the company. Conversely, the inadequacy of working capital is the primary indicator of a company's failure. Working capital was measured by a ratio scale that used the following formula:

Working Capital = Total Current Assets Total Current Liabilities

Return on Assets describes asset turnover measured from sales. The higher the ratio, the better, and this means that assets were utilized effectively to gain profits. Return on Assets is measured by a ratio scale that uses the following formula:

$$
R O A=\frac{\text { Earnings after Interest and Tax }}{\text { Total Assets }}
$$

Return on Equity is a measurement of income available to company owners (both ordinary shareholders and preferred shareholders) for the capital they invest in the company. Return on Equity is measured by a ratio scale that uses the following formula:

$$
R O E=\frac{\text { Earnings after Interest and Tax }}{\text { Equity }}
$$

\section{Results}

The purpose of the partial test is to measure to what extent the influence of the independent variable $(\mathrm{X})$ on the dependent variable (Y) individually. Hypothesis testing will be carried out using a significance level of $0.05(\alpha=5 \%)$ or a confidence level of 0.95 . The t-test in this study aims to determine the effect of independent variables consisting of working capital, return on assets (ROA), return on equity (ROE) on corporate income tax on mining sector manufacturing companies listed on the Indonesia Stock Exchange (BEI) in 2012- 2017.

Based on the results of the t-test, the $t$ value of working capital is 10.773 and $t$ table of 2.056. Because t-value $>\mathrm{t}$ - table can be concluded that $\mathrm{H}_{0}$ is rejected and $\mathrm{H}_{\mathrm{a}}$ 
is supported, it can be concluded that the use of working capital has a significant impact on the corporate income tax (p $<0,05)$.

Based on the results of the t-test, $t$ value Return on Assets (ROA) is 0.944 and $\mathrm{t}$ - table is 2.056. Because $\mathrm{t}$-value $<\mathrm{t}$-table, it can be concluded that $\mathrm{H}_{0}$ is supported and $\mathrm{H}_{\mathrm{a}}$ is rejected. Significant value of Return on Assets (ROA) is 0.354, which is greater than the error rate of $0.05(0.354>0.05)$. Therefore, it can be concluded that Return on Assets (ROA) has no significant impact on the corporate income tax.

Based on the results of the $t$-test, $t$ value of Return on Equity (ROE) is 1,229 and $\mathrm{t}$-table is 2,056. Because $\mathrm{t}-\mathrm{V}$ alue $<\mathrm{t}-$ table, it can be concluded that $\mathrm{H}_{0}$ is supported and $\mathrm{H}_{\mathrm{a}}$ is rejected. Significant value of Return on Equity (ROE) is 0.230 , which is higher than the error rate of 0.05 $(0.230>0.005)$. Therefore, it can be concluded that Return on Equity (ROE) has no significant impact on the corporate income tax.

Simultaneous Test (F-test) was applied to test the model proposed in this study. The output of F-test shows that the significance of the results is 0.000 , and Rsquare is 46.373 . It can be concluded that simultaneously, variables, namely working capital, return on assets, and return on equity have a significant impact on the corporate income tax.

\section{Discussion}

The results show that the use of working capital has a significant effect on corporate income tax. The company that has proper working capital management will affect the level of corporate income tax that the company. According to Suryanto (2012), a company with a high level of profit will have a high increase in capital (net assets). With a high level of net assets, companies can use it to increase their current assets (Yuriwati, 2012). The result is consistent with the previous study conducted by Ida Bagus Putu Fajar Adisamartha and Naniek Noviari (2015).

Return on Assets (ROA) does not significantly influence the Corporate Income Tax. Return on Assets (ROA) describes asset turnover measured from sales. The higher the ratio, the better due to assets were utilized effectively to earn profits. However, the result of this study is not in line with the theory. The population in this study is labor-intensive companies (mining companies). Therefore, the costs incurred are substantial and make the corporate income tax even lower.

Return on Equity (ROE) does not significantly influence the corporate income tax. Factors that influence equity returns are increasing sales without increasing proportional expenses or costs. However, this is not possible for authors to include all population in this study. They are considering that mining companies require higher expenditure to support sales in the production process.

The results showed that simultaneously, working capital, Return on Assets (ROA) and Return on Equity (ROE) significantly influence the corporate income tax. It means that the model proposed in this study can explain the variance of corporate income tax. Mining companies are labor-intensive industries with a substantial level of sales and with significant operational expenses. Therefore, management must manage the use of working capital properly.

\section{Conclusion}

Based on the analysis and discussion in the previous section, the conclusions are as follows; 1) working capital has a significant impact on corporate income tax; 2) Return on Assets (ROA) does not significantly impact the corporate income tax; 3) Return on Equity (ROE) does not have significantly impact the corporate income tax; 4) working capital, Return on Assets (ROA) and Return on Equity (ROE) 
simultaneously influenced the corporate income tax.

The limitation of this study is that the sample used is only limited to financial statements for the period 2012-2017 and only in manufacturing companies in the mining sector. The financial ratios used are only limited to profitability ratios and working capital without using other financial ratios. Based on these limitations, the suggestion for further research is to extend the period of observation and include manufacturing companies with other sub-sectors. Therefore, the results can be more generalized. In the next study, the researcher also suggested the use of different data analysis tests, and the use of other variables, for example, operational costs as determinants of corporate income tax.

In addition, suggestions for corporate are re as follows; 1) properly maintain the use of working capital that occurs in the company so that there is no loss or excess use of working capital, 2) increase the value of sales by minimizing operational costs 3 ) maintain and improve Return on Equity so that investors are interested in investing their capital

\section{References}

Adisamartha, Ida Bagus Putu Fajar dan Naniek Noviari, 2015. "Pengaruh Likuiditas, Leverage, Intensitas Persediaan dan Intensitas Aset Tetap pada Tingkat Agresivitas Wajib Pajak Badan".

Agha, Hina, 2014. "Impact of Working Capital Management on Profitability". European Scientific Journal.10 (1), 374-381.

Casanova, Benny dan Marsellisa Nindito, 2014. "Pengaruh Pajak Tangguhan dan Rasio Pajak Terhadap Kinerja Laporan Keuangan Perusahaan pada Perusahaan yang Terdaftar di Bursa
Efek Indonesia (BEI)". Jurnal Wahana Akuntansi, 9 (2),80-108.

Djarwanto, 2011. Pokok-Pokok Analisis Laporan Keuangan. Edisi Kedua. Yogyakarta: BPFE.

Ghozali, Imam, 2012. Aplikasi Analisis Multivariate Dengan Program IBM SPSS 25. Edisi Kesembilan. Semarang: Badan Penerbit Universitas Diponegoro.

Harahap, Sofyan Safri, 2010. Analisa Kritisatas Laporan Keuangan. Cetakan Ke-11. Jakarta: PT Raja Grafindo Persada.

Harahap, Sofyan Safri, 2013. Analisa Kritis atas Laporan Keuangan. Jakarta: Raja Grafindo Persada.

Harmana, I Made Dwi dan Ketut Alit Suadana, 2014. "Pengaruh Pajak Tangguhan dan Tax To Book Ratio Terhadap Kinerja Perusahaan". EJurnal Akuntansi Universitas Udayana. 6 (3), 468-480.

Kasmir, 2014. Analisis Laporan Keuangan. Ed.1, Cet. 7. Jakarta: Rajawali Pers.

Kasmir, Jakfar, 2009. Studi Kelayakan Bisnis. Edisi Kedua. Cetakan ke 6. Jakarta:Prenada Media Group.

Keown, Arthur J, et al, 2001. Dasar-dasar Manajemen Keuangan. Edisi ketujuh. Jakarta: Salemba Empat.

Lakollo, Antonius dan Syafruddin, M., 2013. "Pengaruh Manajemen Modal Kerja dan Rasio Keuangan Terhadap Profitabilitas pada Industri Manufaktur Yang terdaftar di Bursa Efek Indonesia (BEI) Tahun 2011”. E-Jurnal Undip. 2 (2), 1-13.

Mardiasmo. 2013. Perpajakan Edisi Revisi. Yogyakarta: CV Andi Offset. 
Munawir, S, 2010. Analisis Laporan Keuangan. Edisi Keempat. Yogyakarta : Liberty.

M. Hanafi, Mamduh, Abdul Halim. 2007. Analisis Laporan Keuangan. EdisiKedua. Yogyakarta: UPP STIM YKPN

Putri, Putu Intan Gana dan Sudiartha, GedeMerta, 2011. "Pengaruh Modal Kerja Terhadap Profitabilitas Perusahaan Food and Beverages". Bali. 511- 523.

Resmi, Siti. 2014, Perpajakan Teori dan Kasus. Jakarta: Salemba Empat.

Riyanto, Bambang, 2002. Dasar-Dasar Pembelanjaan Perusahaan. Edisi Keempat. Cetakan keenam. Yogyakarta: BPFE.

Sartono, Agus. 2012. Manajemen Keuangan Teori dan Aplikasi. Edisi Keempat. Yogyakarta: BPFE.

Syamsuddin, Lukman, 2009. Manajemen Keuangan Perusahaan:Konsep Aplikasi dalam Perencanaan, Pengawasan, dan Pengambilan Keputusan. Jakarta: PT Raja Grafindo Persada.

Sugiyono, 2014. Metode Penelitian Kuantitatif, Kualitatif, dan $R \& D$. Bandung: Penerbit Alfabeta.

Takon, Samuel Manyo dan Atseye, Fidelis, Anake, 2015. Effect of Working Capital Management on Firm Profitability in Selected Nigerian Quoted Companies". International Journal of Economics, Commerce and Management. 3 (10), 414-438.

Tohardi, Ahmad, 2002. Pemahaman Praktis Manajemen Sumber Daya Manusia. Universitas Tanjung Pura, Mandar Maju. Bandung.
Undang-Undang Perpajakan No. 28 Tahun 2007

Utami, Made Sri dan Dewi, Made Rusmala, 2016. "Pengaruh Manajemen Modal Kerja Terhadap Profitabilitas Perusahaan Manufaktur yang terdaftar Di Bursa Efek Indonesia”. E-Jurnal Manajemen Unud. 5 (6), 3476-3503.

Waluyo, 2014. Akuntansi Perpajakan. Jakarta: Salemba Empat. 